\title{
Knowledge produced from the outcomes of the "Nursing Outcomes Classification - NOC": integrative review
}

\author{
Conhecimento produzido sobre os resultados da \\ "Nursing Outcomes Classification - NOC": revisão integrativa \\ Conocimiento producido sobre los resultados de la \\ "Nursing Outcomes Classification - NOC": revisión integrativa
}

\author{
Natália Chantal Magalhães da Silva ${ }^{a}$ \\ Ana Railka de Souza Oliveirab \\ Emília Campos de Carvalho ${ }^{a}$
}

ABSTRACT

Objective: To identify the knowledge produced from the outcomes of the Nursing Outcomes Classification (NOC).

Method: A literature review using the integrative databases: Latin American and Caribbean Health Sciences (LILACS), US National Library of Medicine (PubMed), Cumulative Index to Nursing \& Allied Health Literature (CINAHL) and Scopus Info Site (SCOPUS), during the months of August and September 2014.

Results: The review consisted of 21 articles that addressed different issues: Translation and Cultural adaptation (4.77\%); Applicability in clinical practice (33.33\%); and, Validation (63.90\%). Analysis of these articles showed that the knowledge produced from the Nursing Outcomes Classification includes translation and cultural adaptation, evaluation of applicability and validation of its items. Conclusion: Considering the continuous evolution of this classification, periodic reviews should be carried out to identify the knowledge, use and effects of the NOC.

Keywords: Nursing. Classification. Outcome assessment (Health care).

\section{RESUMO}

Objetivo: Identificar o conhecimento produzido sobre os Resultados de Enfermagem da Nursing Outcomes Classification (NOC).

Método: Trata-se de uma revisão integrativa da literatura realizada nas bases de dados: Literatura Latino-Americana e do Caribe em Ciências da Saúde (LILACS), US National Library of Medicine (PUBMED), Cumulative Index to Nursing \& Allied Health Literature (CINAHL) e Scopus Info Site (SCOPUS), durante os meses de agosto e setembro de 2014.

Resultados: Compuseram esta revisão, 21 artigos que abordaram diferentes enfoques: tradução e adaptação cultural de Resultados de Enfermagem e seus indicadores (4,77\%); aplicabilidade dos mesmos na prática clínica (33,33\%); e, validação de seus elementos (63,90\%). Após a análise dos artigos, verificou-se que o conhecimento produzido abordou os aspectos da tradução e adaptação cultural dos Resultados, a avaliação de sua aplicabilidade e a validação de seus itens.

Conclusão: Por apresentar desenvolvimento contínuo, sugere-se a realização de revisões periódicas que identifiquem o conhecimento, uso e efeito da NOC.

Palavras-chave: Enfermagem. Classificação. Avaliação de resultados (Cuidados de saúde).

\section{RESUMEN}

Objetivo: identificar el conocimiento producido sobre los resultados da Nursing Outcomes Classification (NOC).

Método: Se trata de una revisión integradora realizada en las bases de datos: Literatura Latinoamericana y del Caribe en Ciencias de la Salud (LILACS), US National Library of Medicine (PUBMED), Cumulative Index to Nursing \& Allied Health Literature (CINAHL) y Scopus Info Site (SCOPUS), durante los meses de agosto y septiembre de 2014.

Resultados: se componen de esta revisión 21 artículos que abarcaron: Traducción y adaptación cultural (4,77\%); Aplicabilidad en la práctica clínica (33,33\%); y, Validación (63,90\%). Después de analizar los artículos, el conocimiento producido por el NOC de resultados de enfermería incluye la traducción y adaptación cultural, la evaluación de aplicabilidad y la validación de sus artículos.

Conclusión: con la presentación de continuo desarrollo, se sugiere llevar a cabo revisiones periódicas para identificar el conocimiento de la NOC.

Palabras clave: Enfermería. Clasificación. Evaluación de resultado (Atención de Salud).
DOl: $\quad$ http://dx.doi.org/10.1590/19831447.2015.04.53339

\footnotetext{
a Universidade de São Paulo (USP), Escola de Enfermagem de Ribeirão Preto. Ribeirão Preto, São Paulo, Brasil.

b Universidade Estadual de Campinas (UNICAMP), Departamento de Enfermagem. Campinas, São Paulo, Brasil.
} 


\section{DINTRODUCTION}

To achieve quality care, one of the great challenges of nursing consists in establishing a standardized language that promotes communication between the professionals of different health services ${ }^{(1-2)}$.

In recent decades, numerous terminologies have emerged to unify the terms used in the clinical nursing practice. These terminologies include the International Classification for Nursing Practice: (ICNP®), the Clinical Care Classification (CCC), the Omaha System, Nanda-International (NANDA-I), the Nursing Interventions Classification $(\mathrm{NIC})$ and the Nursing Outcomes Classification (NOC) ${ }^{(3)}$.

These terminologies are employed to standardize terms and document the stages of care using standardized language systems ${ }^{(3-4)}$. Nursing Diagnoses proposed by NANDA- $-^{(5)}$ is used to identify a health status or condition.

Similarly, the use of terminologies, such as the NIC, allows the establishment of nursing interventions in case of alterations ${ }^{(6)}$. These terminologies can also help establish expected outcomes that are sensitive to nursing interventions, and to measure the effectiveness of these interventions in terms of the diagnosed clinical condition, as proposed by the $\mathrm{NOC}^{(7)}$.

The NOC emerged from the need to implement a specific language that could be used to evaluate the nursing process $^{(3)}$. In 1991, a group of researchers from the Center of Nursing Classification and Clinical Effectiveness of the College of Nursing at the University of lowa met to create the first version of the taxonomy ${ }^{(7)}$.

In addition to the NOC, there are other strategies for evaluating nursing results. These strategies include the Omaha System, which presents a problems classification scale for the outcomes; the Home Healthcare Classification, which uses the measurements of improvement, stabilization and aggravation (regression) of the presented clinical condition; The Patient Care Data Set, which displays the results for severe cases of hospitalized patients; and The Outcome Assessment Information Set (OASIS), which presents results for patients with specific characteristics ${ }^{(2-3)}$

Given the clear and standardized approach of the NOC and its ease of use with the NANDA-I and NIC taxonomies, it is thought to facilitate the communication between nurses and is considered clinically useful for healthcare practice(2).

This taxonomy, currently in its fifth edition, is composed of seven domains, 31 classes and 490 nursing results. Each result is accompanied by the corresponding definition, indicators and a measurement scale. Each indicator that pertains to a given situation has a score that ranges from 1 (less desirable state) to 5 (most desired state) ${ }^{(7)}$.

In spite of the strategies to assess nursing results, the use of these strategies in the clinical practice is still incipient ${ }^{(2)}$. Thus, in view of the need to incorporate outcome measures in care and considering that the NOC is a viable proposal for this purpose, it is important to identify scientific literature on the subject.

Previous studies ${ }^{(1-2)}$ have verified the knowledge produced from nursing outcomes. The first review ${ }^{(2)}$, conducted in 2007, addressed the growing use of standardized outcome classifications to assess health conditions in professional practice. The last review ${ }^{(1)}$, conducted in 2009, stressed the use of taxonomy in the healthcare practice and in computer systems, and the validation of its elements. At the end of this analysis, the authors of both reviews observed that although taxonomy has been the subject of studies in recent years, in Brazil the use of taxonomy in research, education and clinical practice is still recent ${ }^{(1)}$.

Since this classification is undergoing a successive process of development and refinement, the knowledge that is produced requires continuous evaluation. Consequently, the aim of this paper is to update previous analyses ${ }^{(1-2)}$ by identifying the knowledge produced from the outcomes of the Nursing Outcomes Classification (NOC).

\section{METHODOLOGY}

This is an integrative review of literature. This methodology is used to gather empirical and theoretical data of the investigated subject ${ }^{(8)}$. The guiding question of the study was: "What knowledge is produced from the nursing outcomes of the NOC?".

Data were collected in August and September 2014 from articles in full-text format. Studies published from 2010 to 2014 were analyzed within a time frame of five years, since the last review was in $2009^{(1)}$.

The inclusion criterion was primary studies that used the nursing outcomes of the NOC. Editorial content, opinion-related articles and book chapters were excluded.

The initial search was in the following databases: Literatura Latino-Americana e do Caribe em Ciências da Saúde (LILACS), US National Library of Medicine (PUBMED), Cumulative Index to Nursing \& Allied Health Literature (CINAHL) and Scopus Info Site (SCOPUS), in August and September 2014. Then, since the previous search was considered insufficient, a survey was conducted using keywords, as shown in Table 1. 
The database searches were performed separately by two researchers, and the differences between the results were resolved by consensus with the presence of a third party researcher.

For study selection, the recommendations of PRISMA ${ }^{(9)}$ were observed, as shown in Figure 1.

The information was extracted in the assessment and categorization stage of the studies using an instrument created by the authors. The instrument comprised the items: paper identification, study objectives, methodological design, participants, results, problems/limitations, conclusions and implications for nursing pointed out by the researchers. It should be noted that the categorization of the papers was based on their objectives, since the purpose was to know the new elements of production involving the NOC.

The results and the discussion of the data were presented in a descriptive form to enable the applicability of the review and provide nurses with support material on the use of the NOC.

\section{RESULTS AND DISCUSSION}

Of the 21 articles found on the nursing outcomes proposed by the NOC, six were selected from the LILACS database, two from PUBMED, four from CINAHL and 10 from SCOPUS.

In relation to year, there was a slight increase of publications in 2011. Most of the analyzed studies (57.14\%) were published in non-Brazilian journals and $90.48 \%$ were published in nursing journals. Although studies from Australia, Colombia and Spain were found in the journals, the approaches were focused in Brazil (80.96\%). Two of these studies were conducted in the southeast region, seven in the northeast region and nine in the south region of Brazil.

As for the level of evidence, 95.24\% of the studies were classified as level IV due to their descriptive or qualitative nature, and $4.76 \%$ were classified as level $V$ because they presented the opinion of experts ${ }^{(10)}$.

This reveals a lack of controlled clinical trials involving the NOC, which can be attributed to the recent use of research involving the evaluation of nursing interventions.

Table 1 - Search strategy and number of articles found in the databases, Ribeirão Preto, SP, Brazil.

\begin{tabular}{|c|c|c|c|}
\hline Databases & $1^{\text {st }}$ Search strategy & $\begin{array}{l}2^{\text {nd }} \text { Search } \\
\text { strategy }\end{array}$ & $\begin{array}{l}\text { Articles } \\
\text { found }\end{array}$ \\
\hline LILACS & $\begin{array}{l}\text { ((("ENFERMAGEM") or "avaliacao em ENFERMAGEM") or } \\
\text { "pesquisa em avaliacao de ENFERMAGEM") or "processos de } \\
\text { ENFERMAGEM" [Descritor de assunto] and (("avaliacao de } \\
\text { RESULTADO") or "avaliacao do RESULTADO") or "analise de } \\
\text { RESULTADOs" or "avaliacao de RESULTADOs" or "avaliacao dos } \\
\text { RESULTADOs" or "monitoramento de RESULTADOs" or "pesquisa } \\
\text { de RESULTADOs" or "avaliacao de RESULTADOs (cuidados de } \\
\text { saude)" or "avaliacao de processos e RESULTADOs (cuidados de } \\
\text { saude)" or "avaliacao de RESULTADOs da assistencia ao paciente" } \\
\text { [Descritor de assunto] }\end{array}$ & $\begin{array}{l}\text { Nursing [Words] } \\
\text { and Classification } \\
\text { [Words] and NOC } \\
\text { [Words] }\end{array}$ & 22 \\
\hline PUBMED & $\begin{array}{l}\text { (((((("Outcome Assessment (Health Care)" or "Outcomes Assessment" } \\
\text { or "Outcome Studies" or "Patient Outcome Assessments"[MeSH } \\
\text { Terms])) AND "Nursing"[MeSH Terms])))) AND ("Nursing outcomes" or } \\
\text { "lowa Nursing Outcomes Classification") }\end{array}$ & $\begin{array}{l}\text { ((Nursing) AND } \\
\text { classification) AND } \\
\text { NOC }\end{array}$ & 11 \\
\hline CINAHL & $\begin{array}{l}\text { ((“Outcome Assessment" or "Outcomes Research") AND "Nursing") } \\
\text { AND ("lowa Nursing Outcomes Classification" OR "Nursing outcomes") }\end{array}$ & $\begin{array}{l}\text { ((Nursing) AND } \\
\text { classification) AND } \\
\text { NOC }\end{array}$ & 16 \\
\hline SCOPUS & $\begin{array}{l}\text { (("Outcome Assessment" or "Outcomes Research") AND "Nursing") } \\
\text { AND ("lowa Nursing Outcomes Classification" OR "Nursing outcomes") }\end{array}$ & $\begin{array}{l}\text { ((Nursing) AND } \\
\text { classification) AND } \\
\text { NOC }\end{array}$ & 25 \\
\hline
\end{tabular}

Source: Research data, 2014. 


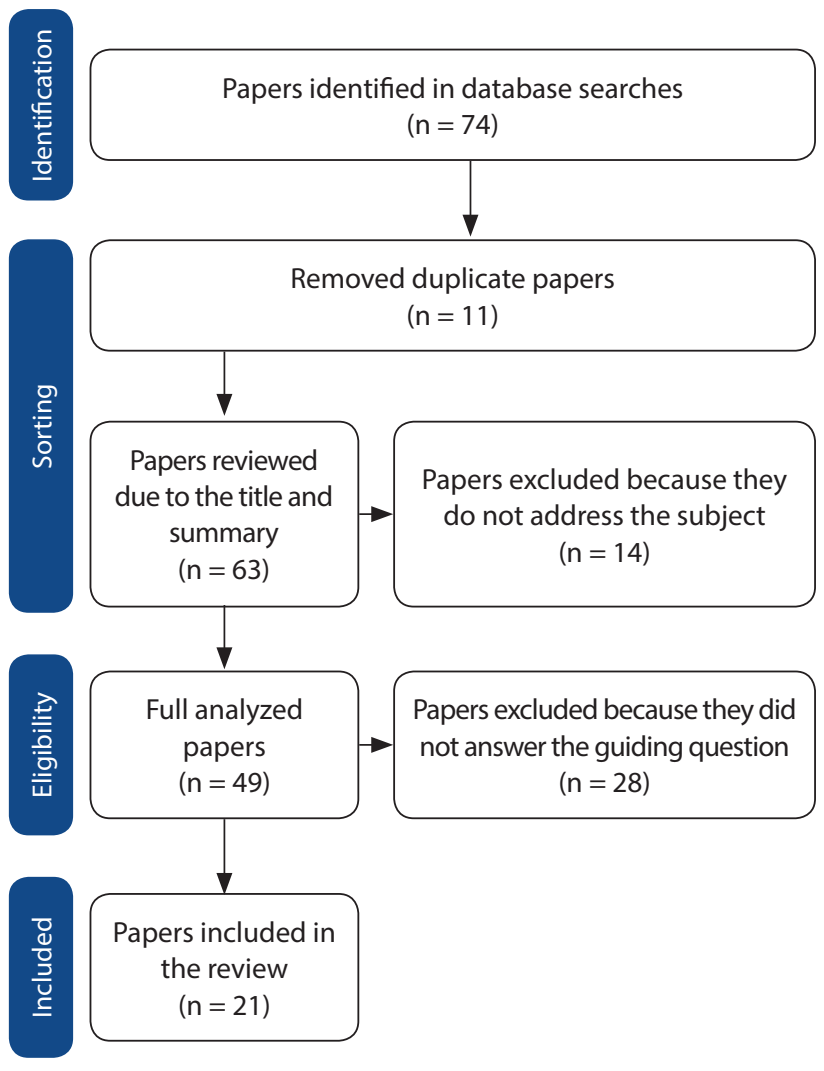

Figure 1 - Flow chart of the selected papers for the integrative literature review, prepared according to $\mathrm{PRISM}^{(9)}$ recommendations

Source: Research data, 2014.

The studies found in this review on the use of nursing outcomes proposed by the NOC were categorized according to the addressed subject. Three categories were subsequently created: Translation and cultural adaptation of nursing outcomes and the associated indicators (4.77\%); Applicability of nursing outcomes in clinical practice (33.33\%); Validation of nursing outcomes (63.90\%).

\section{Translation and cultural adaptation of nursing outcomes and the associated indicators}

The outcomes in the NOC were created in the United States and are presented in English. A translation and cultural adaptation is therefore necessary before the nursing outcomes and their indicators ${ }^{(1)}$ are used in overseas health and education services.

For this assessment tool to be feasible in a given region or country, the items should be translated and back-translated, followed by a semantic assessment of the preliminary version and application in the population by means of a pilot test. This process adapts the terms used in the instrument to the local language based on the cultural characteristics of the region, while maintaining the attributes and equivalence with the original terms ${ }^{(11)}$.

Only one study of this review addressed the translation and cultural adaptation of a NOC result (4.77\%). This study conducted in Spain was based on the translation and cultural adaptation of the title and definition of the indicators in the outcome "Level of pain" found in the fifth edition of the NOC. However, for the Spanish version to be used safely in the clinical practice, studies that test the reliability and validity of this version are required ${ }^{(12)}$.

\section{Applicability of nursing outcomes in clinical practice}

The nursing outcomes of the NOC are being increasingly included in the care provided to patients. When some institutions implement the nursing process, they use this classification to assess the impact, quality and effectiveness of the implemented interventions ${ }^{(13)}$.

In this review, seven studies addressed the applicability of NOC in clinical practice (33.33\%).

A cross-sectional study evaluated the outcomes related to the nursing diagnosis "Ineffective breathing pattern" in children with congenital heart disease. The authors concluded that the employed nursing outcomes helped to differentiate the levels of respiratory impairment in children with and without the referred nursing diagnosis ${ }^{(14)}$. Consequently, the NOC provides a standardized and individualized assessment of patients because it separately assesses the degree of commitment of each analyzed indicator, which helps to plan care according to each of the presented characteristics.

A retrospective study conducted in Australia that sought to characterize the patients who had low scores in the outcomes suggested by the NOC was based on the records of three hospital units. The study showed that women over 70 who were transferred from other hospitals, who had been hospitalized for extended periods, and who, at some moment, had been in an intensive care unit, presented lower outcome scores ${ }^{(15)}$.

Similarly, a study aimed to characterize the health status of patients with venous ulcers according to the indicators proposed for the outcomes "Tissue Integrity: skin 
and mucous membrane" and "Tissue Perfusion: peripheral". The authors reported that the evaluation of skin using the NOC allowed the identification of indicators that usually present low scores in people with venous ulcers, which enables nurses to focus their attention on preventing future complications ${ }^{(16)}$.

In order to identify the presence of risk indicators for the development of pressure ulcers in people with multi-systemic trauma or spinal cord injury, researchers evaluated the skin of patients admitted to a traumatic emergency unit by means of the scale of assessment of the nursing outcome "Tissue Integrity: skin and mucous membranes". The data of the study confirmed that the NOC can be considered an effective method for the identification of risk indicators, since it allows the quantification of the assessed items ${ }^{(17)}$.

In 2009, researchers analyzed fall prevention in patients suffering from cerebrovascular accident using the result of the nursing outcome "Fall prevention behavior" and identified that two indicators - personal caregiver help and the presence of adequate lighting - were not referred to by the sample of the study ${ }^{(18)}$. This fact confirms that the NOC results can be used to characterize a particular population and identify gaps that require the accurate and effective performance of nurses.

Another study verified the applicability of the NOC among orthopedic patients in postoperative care who presented the outcome "Self-care deficit: bathing and toileting". It was noted that the indicators of the outcomes "Selfcare: Activities of Daily Living (ADL)", "Self-care: Bathing", "Self-care: Hygiene" and "Self-care: Oral Hygiene" allowed the monitoring of patients in relation to self-care ${ }^{(19)}$.

A study conducted in 2012 identified the most appropriate nursing outcomes for specific goals documented in the medical records of previously hospitalized patients. Consequently, 28 NOC outcomes were proposed from the following domains: physiological health, functional health, health knowledge and behaviors, and psychosocial health - for 59 goals identified in the reviewed records ${ }^{(20)}$. This suggests that the use of the NOC and its assessment scales allow the standardization of objectives, which helps to determine the effectiveness of nursing care.

The studies presented above suggest that, by promoting an accurate assessment of the individual, the family or the community, the NOC enables the use of nursing strategies to assess health status and prevent undesirable clinical conditions. Although the NOC can be used to monitor the evolution of patients and veri- fy the quality of care, the need to further develop and validate the NOC is imperative, since this is the only way to ensure the applicability of the nursing outcomes in clinical practice.

\section{Validation of Nursing Outcomes}

As the NOC does not present operational definitions or guidelines to measure nursing outcomes, the identification of the indicators at all levels can be different between the professionals, which can cause discrepancies. Studies are being conducted to construct and validate the indicators of certain outcomes. This reveals the concern of researchers in legitimizing the elements that compose the NOC. In this review, 13 studies addressed the validation of NOC outcomes (63.90\%).

The first study aimed to identify evidence on the elements of the nursing outcome "Fall prevention behavior" and build definitions for the indicators. The conducted literature review enabled the construction of definitions and the identification of new and important indicators that were not included in the taxonomy ${ }^{(21)}$. This reveals the need to improve the NOC in order to better guide the selection of nursing interventions by specifically indicating which clinical condition is not ideal and how much the patient needs to evolve.

Of the 13 studies that composed this category, 11 addressed content validation of the nursing outcomes. This consists in the analysis of one or more terms by researchers based on literature and by experts based on their experience ${ }^{(22)}$.

Along these lines, Brazilian researchers focused on validating the content of the outcome "Tissue Integrity: skin and mucous membranes" in people with diabetes mellitus type 2. After the integrative review of literature, the indicators and their definitions were assessed by seven expert nurses and presented an excellent level of acceptance ${ }^{(23)}$.

Another study that was conducted in Brazil validated the content of the nursing outcomes related to the diagnosis "Acute pain". The study concluded that additional studies were required to validate these outcomes in a variety of populations in order to reach a high level of applicability in clinical practice ${ }^{(24)}$.

In 2013, a study validated the content of the nursing outcomes related to the nursing diagnoses "Ineffective Breathing Pattern" and "Impaired Spontaneous Ventilation". The nurses of a university hospital judged each outcome and its indicators in relation to their importance 
for each of the two diagnoses. It was concluded that the NOC is valid in the studied context and presents the elements that nurses need to assess patients during their daily care routine ${ }^{(25)}$.

The content of four nursing outcomes - Self-care: Activities of Daily Living (ADL), Self-care: Bathing, Self-care: Hygiene and Self-care: Oral Hygiene, related to the diagnosis "Self-care deficit: bathing/toileting" presented by Brazilian patients in postoperative orthopedic care, were also validated by 37 nurses ${ }^{(26)}$.

Another two studies validated the content of outcomes related to two nursing diagnoses that are often identified in hospitalized patients in clinical, surgical and intensive care units in Brazil ${ }^{(27)}$ and the content of the outcomes for pediatric patients who had received the nursing diagnosis "Deficient diversional activities"(28).

A study that aimed to validate the nursing outcome"Mobility" in stroke victims found that this outcome facilitated the accurate assessment of the capacity of locomotion ${ }^{(29)}$.

In 2010, Colombian researchers determined the content validity of the outcome "Treatment behavior treatment: illness or injury" to measure adherence to treatment of patients diagnosed with hypertension. The data indicated that this result provides scientific evidence to support its application in practice. However, the authors of the study recommended further studies to assess criterion validity and test its discrimination capacity to verify adherence to treatment for hypertension and strengthen the establishment of a standardized nursing language $\mathrm{e}^{(30)}$.

A study carried out in Spain in 2011 aimed to obtain further insight into interobserver reliability of NOC outcomes in chronic patients who exhibit"Ineffective self health management". The data proved that two indicators - believing the information provided by healthcare professionals and the description of emergency measures - presented unacceptable reliability values. Consequently, the study limitation was the lack of conceptual and operational definitions, since there was no standardization of the assessment of these indicators ${ }^{(31)}$.

The importance of studies that validate the language of nursing, such as the NOC, for the construction and certification of professional knowledge is remarkable. However, it is also necessary to validate this taxonomy in the real-life environment and subsequently assess the clinical applicability of nursing outcomes ${ }^{(28)}$.

Few researchers have based their studies on the clinical validation of nursing outcomes ${ }^{(22)}$, as observed in this review, in which only one study adopted the strategy.
This study, conducted in the northeast of Brazil, established the clinical validity of NOC outcomes that assess the respiratory status of children with congenital heart disease. Firstly, conceptual and operational definitions were created for the nursing outcome indicators "Respiratory status: ventilation”, "Respiratory status: airway patency" and "Respiratory status: gas exchange". Subsequently, the set of indicators and their definitions were submitted to 13 expert nurses for evaluation ${ }^{(23)}$.

The referred clinical validation study consisted of the assessment of children with congenital heart disease by 8 previously trained nurses. The nurses were divided into pairs. Two pairs evaluated the children by using indicators and their definitions and the other pairs evaluated the children using the indicators without their definitions. The evaluations obtained from operational definitions without the definitions were inconsistent. These inconsistencies, however, were not found in the group that used the definitions ${ }^{(23)}$.

Therefore, in order to ensure the use of outcomes in nursing care, education and research, their applicability must be verified in the real-life clinical environment, which should essentially lead to the clinical validation of the outcomes.

\section{CONCLUSION}

The results of this integrative review revealed the following evidence on the knowledge produced from the NOC outcomes:

- Translation and cultural adaptation of NOC items for use in various scenarios, where the version was not yet available.

- Evaluation of NOC applicability in the real clinical scenario to monitor the evolution of patients and check the quality of care.

- Validation of its elements by constructing conceptual and operational definitions validated by an expert and clinically tested to identify greater a better uniformity of each indicator; or by verifying the outcome and its indicators in a real clinical scenario to measure the outcome of the patient's clinical condition.

This classification, though recent, is a viable alternative to assess and identify the best nursing practices, since it provides care quality indicators that help determine the effectiveness of the care provided by nurses.

This review clearly showed a growing number of studies with the NOC in Brazil in the past five years, which sug- 
gests that the classification has been gaining ground in the national research scenario. Similarly, the high number of studies that aims to validate the nursing outcomes reduces concerns of legitimizing the elements of the classification before its implementation.

However, since research with NOC outcomes could be indexed in other formats, the fact that the database search did not include dissertations and theses can be considered a limitation of this review.

Components of the NOC are continuously being included, refined and reformulated. Consequently, it should continue being the subject of studies that address the translation and cultural adaptation of its outcomes and indicators, the applicability of its items, and the validation of nursing outcomes in the real clinical scenario in different contexts and populations. Further reviews are therefore recommended to update the evidence found in clinical and academic practices.

\section{REFERENCES}

1. Garbin LM, Rodrigues $C C$, Rossi LA, Carvalho EC. Classificação de resultados de enfermagem (NOC): identificação da produção científica relacionada. Rev Gaúcha Enferm. 2009;30(3):508-15.

2. Seganfredo DH, Almeida MA. Produção de conhecimento sobre resultados de enfermagem. Rev Bras Enferm. 2010;63(1):122-6.

3. Cubas MR, Denipote AGM, Malucelli A, Nóbrega MML. The ISO 18.104: 2003 as integrative model of nursing terminologies. Rev Latino-Am Enfermagem. 2010;18(4):669-75.

4. Shiu AT, Wong RY. Diabetes foot care knowledge: a survey of registered nurses. J Clin Nurs. 2011;20(1):15-6.

5. NANDA-I. Nursing diagnoses: definitions e classification (2012-2014). Oxford: Wiley-Blackwell; 2012.

6. Bulechek GM, Butcher HK, Dochterman JMM, Wagner C. Nursing Intervention Classification (NIC). 6th ed. St. Louis: Elsevier; 2013.

7. Moorhead S, Johnson M, Mass ML, Swanson E. Nursing Outcomes Classification (NOC): measurement of health outcomes. 5th ed. St. Louis: Elsevier; 2013.

8. Whittemore R, Knaf K. The integrative review: update methodology. J. Adv Nurs. 2005;52(5):546-53.

9. Lillemoen L, Pedersen R. Ethical challenges and how to develop ethics support in primary health care. Nurs Ethics. 2012;20(1):96-108.

10. Melnyk BM, Fineout-Overholt E. Evidence-based practice in nursing and healthcare: a guide to best practice. 2nd ed. Philadelphia: Wolters Kluwer; 2011.

11. Guillemin F, Bombardier C, Beaton D. Cross-cultural adaptation of health-related quality of life measures: literature review and proposed guidelines. J Clin Epidemiol. 1993;46(12):1417-32.

12. Bellido-Vallejo JC, Rodríguez-Torres MC, Lopez-Medica IM, Pancorbo- Hidalgo PL. Adaptación cultural y validación de contenido del resultado "nível del dolor" de la classificación de resultados de enfermería. Enf Clínica. 2013;23(4):154-9.
13. Silva NCM, Chaves ECL, Carvalho EC, lunes DH. Instrumento para avaliação da integridade tissular dos pés de portadores de diabetes melittus. Acta Paul Enf. 2013;26(6):535-41.

14. Beltrão BA, Silva VM, Araújo TL, Lopes MVO. Clinical indicators of ineffective breathing pattern in children with congenital heart diseases. Int J Nurs Term Classif. 2011;22(1):4-12.

15. Schreuders LW, Bremner AP, Geelhoed E. Using linked hospitalisation data to detect nursing sensitive outcomes: a retrospective cohort study. Int J Nurs Stud. 2014:51(3):470-8.

16. Sampaio Santos FAA, Melo RP, Lopes MVO. Characterization of health status with regard to tissue integrity and tissue perfusion in patients with venous ulcers according to the nursing outcomes classification. J Vasc Nurs. 2010;28(1):14-9.

17. Sampaio Santos FAA, Vitor AF, Teixeira IC, Melo RP, Lopes MVO. Skin inspection for evaluating the presence of risk indicators to developing pressure ulcers. Aust J Adv Nurs. 2012;29(3):40-8.

18. Oliveira ARS, Costa AGS, Sousa VEC, Moreira RP, Araújo TL, Lopes MVO, Galvão MTG. Condutas para a prevenção de quedas de pacientes com acidente vascular encefálico. Rev Enf UERJ. 2011;19(1):107-13.

19. Almeida MA, Seganfredo ODH, Unicovsky MR. Validação de indicadores da classificação dos resultados de enfermagem para pacientes com problemas ortopédicos. Rev Esc Enf USP. 2010;44(4):1059-64.

20. Chianca TCM, Salgado PO, Albuquerque JP, Campos CC, Tannure MC, Ercole FF. Mapeamento de metas de enfermagem de uma unidade de terapia intensiva por meio da classificação de resultados de enfermagem. Rev Latino-Am Enfermagem. 2012;20(5):1-10.

21. Vitor AF, Araújo TL. Definições para o resultado de enfermagem "comportamento de prevenção de quedas": uma revisão integrativa. Rev Eletr Enf. 2011;13(2):313-22.

22. Carvalho EC, Cruz DAL, Herdman H. Contribuição das linguagens padronizadas para a produção do conhecimento, raciocínio clínico e prática clínica da enfermagem. Rev Bras Enf. 2013;66(n.esp):134-41.

23. Silva VM, Lopes MVO, Araujo TL, Beltrão BA, Monteiro FPM, Cavalcante TF, et al. Operational definitions of outcomes indicators related to ineffective breathing patterns in children with congenital heart disease. Heart Lung. 2011;40(3):70-7.

24. Lucena AF, Holdbach I, Pruinelli L, Cardoso ASF, Mello BS. Brazilian validation of the nursing outcomes for acute pain. Int J Nurs Knowl. 2012;24(1):54-8.

25. Canto DF, Almeida MA. Resultados de enfermagem para padrão respiratório ineficaz e ventilação espontânea prejudicada em terapia intensiva. Rev Gaúcha Enferm. 2013;34(4):137-45.

26. Almeida MA, Seganfredo ODH, Canto DF, Barreto LNM. Aplicabilidade da classificação dos resultados de enfermagem em pacientes com déficit no autocuidado: banho/higiene. Rev Gaúcha Enferm. 2010;31(1):33-40.

27. Seganfredo GH, Almeida MA. Nursing outcomes content validation according to Nursing Outcomes Classification (NOC) for clinical, surgical and critical patients. Rev Latino-Am Enfermagem. 2011;19(1):34-41.

28. Almeida MA, Silva MB, Panato BP, Siqueira APO, Lauent MCR. Nursing outcomes for Brazilian pediatric patients hospitalized with deficient diversional activity. Int J Nurs Knowl. 2013;24(2):85-92. 
29. Moreira, P, Araúijo TL, CavalcanteTF, Guedes NG, Costa AGS, Lopes MVO. Validation of the mobility nursing outcome in stroke survivors. Int J Nurs Knowl. 2013;24(3):157-62.

30. Esteban AN, Caballero LPD, Barbosa NL, Oróstegui MA, Vargas LCO, Valencia LIA. Construct validity of an instrument to assess patient adherence to antihypertensive treatment. Enferm Glob. 2014;34(1):48-57.
31. Morrila-Herrera JC, Marales-Asencio JM, Fernández-Gallego MC, Cobos EB, Romero AD. Utilidad y validez de un instrumento basado en indicadores de la Nursing Outcomes Classification como ayuda al diagnóstico de pacientes crónicos de atención primaria con gestión ineficiente de la salud propia. 2011;34(1):51-61.

\section{Author's address:}

Natália Chantal Magalhães da Silva

Av. Bandeirantes, 3900, Vila Monte Alegre

14040-902 Ribeirão Preto - SP

Email: nchantal@usp.br
Received: 07.02.2015

Approved: 05.08.2015 